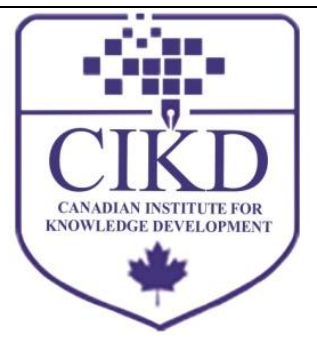

\title{
How Cultural Differences Influence Conflict Within an Organization: A Case Study of Near East University
}

\author{
Ayşe Gözde Koyuncu ${ }^{1 *}$, Rufaro Denise Chipindu ${ }^{2}$ \\ ${ }^{1}$ Faculty of Economics and Administration Science Near East University \\ ${ }^{2}$ Near East University
}

\begin{abstract}
Keywords:

Culture, Cultural

differences, Conflict,

Cross-cultural conflict

\section{Received}

05 November 2018

Received in revised form

09 March 2019

Accepted

11 March 2019

Correspondence:

aysegozde.koyuncu@neu.edu.tr

The culture that people come from has played an important part in shaping any society. Culture is of vital importance since it assists in the way people live and articulating the manner in which information among people is administered. Miscommunication often arises due to the differences in cultures that exist that leads to people misunderstanding of other cultural contexts. Individuals from certain cultures may deal with conflict easily while others tend to find it difficult in dealing with it amenably. This leads to the system of sweeping it under the carpet (De Drue, Blom, \& Hagendoom, 2007). Conflict is triggered when there are cultural differences between individuals within an organization or through general interaction with one another. This often leads to cross-cultural conflict which generally occurs in the context that individuals are not willing to understand each other's diversity in cultures. This study examines cultural differences that influence conflict within an organization. Quota Sampling was used as sampling technique. Data was grouped according to ethnicities. The study is qualitative in nature and made use of semi-structured interviews which were carried out with fifty participants from three ethnic groups. Data was analyzed using Qualitative Content analysis. Findings suggested ways that management could reduce conflict by creating an environment where all cultures interact with one another freely.
\end{abstract}

(C)AIMI Journals

\section{Introduction}

When people come from diverse cultures they are bound to misunderstand one another or rather clash on various issues. According to Hofstede (1980), culture is regarded as the way in which a person's mind is fixed that tends to distinguish people from one group to another in 
terms of what they value and their backgrounds. Culture is an aspect that is important in evaluating the way people behave and react in a certain way around others. Ross (1997) mentioned that culture is an aspect that influences conflicts and plays a vital role in most of them. In addition, despite the fact that culture influences conflict, it does not, however, generate it; hence the two are intertwined in a certain way (Avruch, 2009). The way people communicate with each other is often influenced by their culture.

The cultural differences that exist in an organization infuse conflicts. Culture plays a role in influencing conflict by outlining people's insights on conflict (Worchel, 2005). It was established that culture played two vital roles in conflict. Firstly, ethnicity and culture of a person was noted to serve as a way to establish the different groups that are involved in the conflict. Secondly, the role that culture plays in an intragroup which outlines people's perception of conflicts in a society. The lack of acknowledgement of the differences that exist among people from diverse cultures leads to clashing arising (Kaushal \& Kwantes, 2006). Conflict that focuses on an individual's identity has a cultural element in it. The different cultural disciplines that people are accustomed to cause conflicts amongst different groups in the society which often leads to relationships being strained (Avruch, 2009).

\section{Culture Theories}

There are many theories that were created to support the cultural differences that exist in different societies around the world. The influence that cultural differences have on conflicts that arise in organizations are due to the fact that people react and deal in situations differently (Halverson \& Tirmizi, 2008). The focus of the present study is on establishing the cultural theories that exist and how conflict is influenced between parties in the cultural contexts.

\section{Geert Hofstede}

Geert Hofstede is one of the researchers that established the five dimensions of culture that showed the differences in cultures around the world. These were established to show the cultural differences in different countries (Hofstede, Hofstede, \& Minkov, 2010).

Collectivism-Individualism is the first dimension that helps people operating in an organization in assessing how these cultural differences can influence conflict. Individualist cultures are centered on an individual's needs and personal desires. These people are seen to be autocratic in nature since they dominate others (Weldon \& Jehn, 1995). The Americans and British people are individualist in nature. These people prefer consider teamwork as a draw back and hindrance to completing tasks as well as attainment of goals. Individualist are prone to influencing conflict due to the fact that they work alone and cannot work with others and hence they do not consider opinions or contribution of others (Triandis, 2001). Collectivist are people who work in a group context where much emphasis is on achieving goals as a team. These people share resources with each other and value each individual contribution to the group. The people that are associated in the group are Africans and Asians (Raffery \& Tapsell, 2001). Conflict may be influenced when some individuals may want to gain control of the group. This leads to misunderstandings occurring especially when an individual within the group context may be seen as being a threat to others due to their distinctive traits. 
Power Distance is a dimension that focuses on status of people within the society which divides them into separate groups. It shows the authority that superiors have over subordinates within an organization (Koerner, 2006). The people that come from countries with a large power distance tend to differentiate each other in terms of levels within the society. Conflict often occurs when there is an abuse of power by management in terms of mistreating people within an organization pertaining to task performance (Shadid, 2007). Small power distance cultures are focused on treating everyone equally within the organization (Halverson \& Tirmizi 2008). Uncertainty Avoidance is the other dimension. Cultures with a weak uncertainty avoidance do not enjoy rules that are implemented which are not written down. However, cultures with a strong uncertainty avoidance follow rules that are set within the organization (Hadi, 2004). These people are loyal and committed to the organization. An organization that has a strong uncertainty avoidance tends to push people in resisting any changes that may be implemented. Conflict may be influenced when management implements new rules or structures forcing people to accept them which leads to disagreement arising due to being unable to listen to their views on what they will be implementing (Overton \& Lowry, 2013).

Masculinity-Femininity is the dimension that focuses on the roles that males and females play in the society. Masculine cultured societies focus on achieving their goals and performance driven while feminine cultures are too soft and modest. Scandinavian countries are societies that are dominated by females while Japanese and Arabic countries are is influenced by the cultural differences when females operating in a masculine male dominated. Conflict dominated societies are discriminated in terms of promotions especially when they have the capacity to perform the tasks given to them.

Long-short term orientation is a dimension that focuses on time and the way it impacts the future. Emphasis is made by long term orientation cultures on the future rather than what is in the present. Short term oriented cultures believe that the past and present are linked together (Basset, 2005). People such as these are quick at completing tasks and hence an organization gets their desired results. When short term oriented people make rushed decisions they influence conflict with long term oriented people in that they may feel their rushed decision making may jeopardize everyone operating in the organization.

\section{Fons Trompenaars}

This researcher conducted further research on cultural dimensions by establishing seven dimensions. The dimensions that were created showed the different cultures that exist in the society (Thomas, 2008).

Universalism-Particularism: Cultures that are universalistic in nature focus on rules which deal with cases that are equal (Trompenaars \& Woolliams, 2003). People in this culture need to adhere to the rules and the relationships are created with others. Conflict may be influenced in an organization when implementing rules may affect others. For example, a rule may be placed stating that women cannot wear hijabs to work can cause conflict to arise because people cannot change their cultural beliefs to fit in a working environment (Trompenaars \& HampdenTurner, 2004). Particularistic cultures are more centered on relationships being created rather than following rules that may be set for them. The circumstances that a person is in during 
occurrence determine whether the person is right or wrong. Russians and Chinese people are associated with this culture (Trompenaars \& Hampden-Turner, 1997).

Individualism-Communitarianism: Decision is often made individually and hence rewards are given for their individual effort (Halverson \& Tirmizi, 2008). Communitarian cultures focus on working as a group and goals and objectives are set as a group. Decision making is mostly done in a collective nature and a consensus is reached together as one team; therefore, nepotism becomes eluded (Trompenaars \& Hampden-Turner, 1997). Individualist cultured people are prone to having misunderstandings with others in that they focus on their own goals and desires without considering other people's views or contributions to a given task or assignment. People who have a communitarian culture are prone to influencing conflict with people within the group where certain people within the group may feel that their ideas are not being heard or often overlooked and may feel they are being sidelined (Shadid, 2007).

Specific-Diffuse: Cultures that are diffusive in nature tend to combine their personal and work life together. Diffusive cultures value qualities such as loyalty, appreciativeness and ambiance (Gesteland, 2000). In this culture, employees are able to have meetings with their bosses outside work environment. In specific cultures, work life is never mixed with their personal life and their relations with colleagues remain in the workplace. The differences in cultures often impact on misunderstandings arising between parties. People from diffusive cultures may feel that the completion of tasks is completed faster when they work after hours and sacrifice their lunch time. However, people from specific cultures may not be willing to sacrifice their lunch time or outside working hours to complete a task given to them (Trompenaars \& Hampden-Turner, 1997).

Emotional-Neutral: Neutralist cultures pay much emphasis on elimination of personal sentiments on decision making process within an organization (Halverson \& Tirmizi, 2008). Emotional cultured people express their emotions and feelings as well as physical contact with others. Trompenaar and Hampden-Turner (2006) stated that there is lack of clear understanding and knowledge of practices that these cultures influence conflict within the organization. People with a neutralist culture view people who express feelings as being unprofessional in the workplace while emotional cultural people may view neutralist people as being disrespectful due to their inability to portray emotions.

Achievement-Ascription: In achievement cultures, people are driven by their status based on their performance and accomplishments over time (Trompenaars \& Hampden-Turner, 1997). Ascription cultures focus on an individual who is in society and hence status is given according to who you are (Trompenaars \& Hampden-Turner, 2004). Organizations are certain to clash with one another due to the fact that when one is focused on being ascription culture oriented and the other being achievement culture misunderstands each other when communicating with one another (Luthans \& Doh, 2012).

Synchronic-Sequential: Sequential cultures value time in terms of completing tasks giving on time. The issue of punctuality is important and hence arrival to a meeting or a lecture late is often considered disrespectful or rude (Luthans \& Doh, 2012). Synchronic cultured people tend to multi-task many things at the same time and have less preference on time. Many tasks are often done interchangeably and the targets are often flexible for such people (Trompenaars \& Hampden-Turner, 1997). Conflict follows when a synchronic cultured people believe that plans 
in a project may be moved; whereas, sequential cultured people believe plans drawn should be stuck and hence these differences influence the rise in clashes.

Internal-Outer Direction: Inner direction culture views that for people to achieve their goals they ought to take control of the environment they operate in. Trompenaars and HampdenTurner (1997) stated that people who have internal direction culture are aggressive in nature. In outer directional cultures are peaceful people who strive to maintain good relationships with others (Halverson \& Tirmizi, 2008). People that come from outer direction cultures often manage conflicts easily with others by having discussions that are open with others and finding the best solution to the issue. Internal directional cultures are prone to influencing conflicting with others due to their aggressive behaviors and attitude towards other people (Gudykunst \& Kim, 2003).

\section{High-Low Context Communication Theory}

This theory was created by Edward Hall to show the way different cultures communicate (Wurtz, 2005). Hall (1990) stated that it is important to understand that people come from different cultural backgrounds which need to be understood for easier communication with others. Low context cultures are often associated with being individualistic in nature and communication is direct and simple enough to understand (Imada, 2012). In high context cultures, the focus is on non-verbally communication making use of gestures and the voice tone. These people are collectivistic in nature and group needs are more important than what an individual wants.

Conflict within an organization is influenced when employees from different cultural contexts clash in terms of tasks being completed on time (Tung, 2002). When assigned with a task, low context cultures pay particular attention to meeting deadlines and they are bound to clash with people from high context cultures in that meeting deadlines is not vital to them as long as tasks are completed (Hall, 1990).

\section{Conflict}

This a clash of interests of one group or individual with that of another group or individual where arousing of emotions occurs and hence solving the conflict with compromising strategy is nullified (Cole, 2005). Mensah and Effah (2003) believed that conflict occurs when party interests are different and their views and opinions are always right over the other. Kaushal and Kwantes (2006) mentioned that the way people's lifestyles are often busy tends to influence conflicts in the society. The way people focus on their personal needs first over others often leads to behaving in a certain way towards others. Mullins (2007) mentioned that behavior of an individual changes due to conflict and hence he/she strives to hinder other people from achieving their goals.

\section{Types of Conflicts}

According to Schermerhorn, Hunt, Osborn, and Osborn (2004), the types of conflict that exist include intergroup, interpersonal, intrapersonal, intragroup and intercultural conflicts. $\mathrm{He}$ recognized that three types of the conflicts were influenced by some cultural factors. 
Intergroup, intragroup and intercultural conflicts were influenced by people having a different religion, language and values.

Interpersonal Conflict: This is a conflict that negatively affects performance of individuals within an organization (Barki \& Hartwick, 2004). The conflict occurs when people have personalities that are different which results in clashes occurring due to their differences in opinions (Slocum \& Hellriege, 2007). Schat, Frone, and Kelloway (2006) established that conflict that is interpersonal was found within an organization ranging from gossips and arguments that are petty.

Intrapersonal Conflict: Slocum \& Hellriege (2007) gave an example to an individual decision on a job position in two institutions which possess challenges on the salary and location. The researchers added that this conflict occurs when an individual is given task to complete by his or her superior that he or she regards it as to being unethical. The conflict within yourself occurs on whether to carry out the task that is wrong in your eyes or rather to refuse and take risk of being dismissed. Dimas (2007) indicated that the values and principles an individual has are guided by this type of conflict.

Intragroup Conflict: Thomas (2008) stated that intragroup conflict occurs due to incompatibilities among some members of a team. Members of a group have a tendency of forming sub-groups which often leads to conflict in that the overall group performance becomes affected (Slocum \& Hellriege, 2007). Coleman and Kugler (2014) highlighted that certain members of a group often display behaviors that lead or trigger conflict within the group.

Intergroup Conflict: Intergroup conflict is defined as disagreements that arise between group members in the same group or with other groups (Thompson \& Janice, 2000). Fisher (2001) argued that conflicts that are intergroup transpire due to the different interests and hence this influences the attitude that members have towards other groups. Herriot (2007) stated that religion as a cultural factor is important for a group in securing its identity and hence conflict occurs due to fault lines in religion. Religion is not always a factor that influences conflicts within a group however it serves as an identity element that separates groups that are clashing with each other (Saroglou \& Cohen, 2013). Kashima (2016) argued that religion is an underlying factor in culture that influences intergroup conflict.

Intercultural Conflict: Oetzel \& Ting-Toomey (2003) defined intercultural conflict as being the mismatch of beliefs and inharmoniousness of goals that arise when communicating with people from diverse cultures. The attitude and behavior that people have towards each other results in conflicts arising which leads to complex situations occurring (Ting-Toomey \& Oetzel, 2001). Oetzel and Ting-Toomey (2003) pointed out that miscommunication and misunderstanding between parties were the reason for intercultural conflict arising. The breakdown in communication between parties occurs due to being unaware of other people's cultural forms of communication. Intercultural conflict is associated with the diverse cultures, languages and mentalities that individuals have (Ling \& Lim, 2007). Conflicts that are intercultural ensue in an institution full of people from diverse cultures. This leads people having strained relationships usually because of people misunderstanding other people's cultures or rather degrading it. 


\section{The Cultural Factors Constituting to the Difference that Influence Conflict}

According to Shadid (2007), cultural factors influence the way people behave and react to certain situations in different ways. Cultural factors such as religion, communication, values and gender play a pivotal role in influencing conflicts within an organization.

Religion: The main factor that is seen to influence conflicts in societies is religion (Weigel, 1991). Huntington (1993) stated that religion is a social factor that is often unseen as having an influencing element to most conflicts that arise in societies. Griffen and Pustay (1999) mentioned that what shapes an individual in terms of their attitude towards others is religion. The values a person has helps in the commitment an individual has to their religious beliefs which is a vital element in religion. Religion is a cultural factor that is indented in everyone who come from different nationalities which has been noted to have an influencing element in conflicts that is high. Conflict tends to be influenced when an organization implements certain policies that focus on a specific religious practice and hence not accommodating other religions often triggers clashes amongst people (Triandis, 2001).

Communication: Communication has been noted as being the hub of majority of conflicts. Cultural-induced language conflict occurs when people from diverse cultures communicate exhibiting different attitude towards each other which often leads to misunderstandings occurring (Gao, 2002). This is due to the issue of people miscommunication between people which then halts the interaction between individuals or groups leading to relations to become strained. Shadid (2007) mentioned that when there is miscommunication, conflict is influenced between individuals that come from different cultural backgrounds.

Gender: The way people react in certain situations they are placed in, differs from females to males (Robbins \& Judge, 2011). Gender is what a person is born as in terms of the way they are created and their characteristics of being either male or female (Woods \& Eagly, 2015). Gender plays a role in influencing conflicts within an organization (Reilly \& Neumann, 2013). Conflict is bound to arise within an organization that has both males and females operating together. According to Wood and Eagly (2009), human beings that operate within the same society are bound to conflict with one another. The issue of people who stereotypes often influence conflicts when there is gender discrimination occurring (Saroglou, 2008).

Values: Values are regarded as to what people view as being significant to their day to day living (Schwartz, 1992). Conflicts arise when people have objectives that are different because of the fact that each individual has values that they uphold highly that may not be in line with others (Bartos \& Wehr, 2002). Most people have values that are grounded within them which is often difficult to change. It has been established that majority of people recognize the importance of their values when they are challenged by others. People fail to understand that values differ from one individual to another which often leads to conflicts.

\section{Method}

The main purpose of this study is to establish how cultural differences that exist in the organization influence conflict. Exploratory research was employed to answer the "how" on the research topic. The research strategy used was case study. Qualitative research technique was applied as the appropriate method for this study. It gives an in-depth information pertaining to 
this research. Qualitative research method processes meanings that are not tested experimentally in terms of their quantity and amount (Denzin \& Yvonna, 2000).

The data analysis includes the elucidation, assessment and contrast of information collected from individuals (Hatch, 2002). Qualitative research is the comprehensive analysis of information which considers the existence of individual cultural differences in the society. In addition, this method was used as it provides a complete and systematic representation of the research study.

Interview technique was used as the research instrument for the study which works hand in hand with qualitative research method. Interviews gives the researcher in-depth information given by participants which assist in acquiring detailed information pertaining to the topic being analyzed. Interviews are often conducted in a conducive environment which allows face to face interaction between two parties revealing opinions and views pertaining to the questions asked. The interview questions were guided by themes that focused on the area being studied.

Interviews were conducted for about 30 minutes and questions asked were open-ended. The method that was used for qualitative data analysis in this research was Qualitative Content Analysis. This is the method that is used when recording information given by the participants. Mayring (2014) established that qualitative content analysis assists a researcher in managing and coding of data in well-organised manner.

There has not been much related literature on both subjects being brought together. The interviewer during the interview documented information by taking down notes on a record sheet while the interviewee spoke. By doing so, it reduced the biasness that qualitative research is associated with. Upon completing this, the researcher identified the data and placed it under set themes and codes. The data was then placed in a coding scheme and was grouped for data analysis.

\section{Participants}

The study focused on individuals from diverse cultures who are part of the employees and students at Near East University. The participants were ages from twenty to sixty-five which includes both genders that operate within the organization. The size of the sample for the research study was limited to fifty participants since qualitative research focuses on a small sample size. Table 2 shows the list of participants who contributed to the study by giving their responses to questions asked. 
Table 2

Research Participants

\begin{tabular}{lccc}
\hline $\begin{array}{l}\text { Respondents } \\
\text { R })\end{array}$ & Age & Nationality & Department/Office \\
\hline 1 & 24 & Kenyan & Accounting \\
2 & 27 & Ethiopian & Business Administration \\
3 & 22 & Jordanian & Nursing \\
4 & 43 & Turkish & Tourism \\
5 & 30 & Turkish & Law \\
6 & 24 & Zimbabwean & Marketing \\
7 & 30 & Syrian & Psychology \\
8 & 40 & Turkish & Economics \\
9 & 24 & Saudi Arabian & Computer Engineering \\
10 & 25 & Tswana & Medicine \\
11 & 26 & Ghanaian & Banking and Finance \\
12 & 22 & Lebanese & Mechanical Engineering \\
13 & 28 & Ugandan & Innovation Management \\
14 & 39 & Turkish & Economics \\
15 & 30 & Turkish-Cypriot & 4 \\
16 & Turkish & International \\
17 & 25 & Yemen & Communication \\
\hline
\end{tabular}

Table 2 (Continued)

\begin{tabular}{|c|c|c|c|c|}
\hline $\begin{array}{l}\text { Respondents } \\
(\mathrm{R})\end{array}$ & Age & Nationality & Department/Office & $\begin{array}{c}\text { Study/Work } \\
\text { Period }\end{array}$ \\
\hline 18 & 32 & Libyan & Marketing & 3 \\
\hline 19 & 24 & Ethiopian & International & 2 \\
\hline 20 & 22 & Angolian & International Relations & 2 \\
\hline 21 & 26 & Congolese & Pharmacy & 3 \\
\hline 22 & 22 & Zimbabwean & Economics & 2 \\
\hline 23 & 24 & Syrian & International Relations & 3 \\
\hline 24 & 20 & Palestinian & Banking and Finance & 1 \\
\hline 25 & 50 & Turkish & Law & 5 \\
\hline 26 & 34 & Iranian & Computer Engineering & 4 \\
\hline 27 & 32 & Turkish & International & 3 \\
\hline 28 & 26 & Lebanese & Banking and Finance & 2 \\
\hline 29 & 27 & Turkish & International Office & 2 \\
\hline 30 & 42 & Turkish & Tourism & 5 \\
\hline 31 & 25 & Zimbabwean & Marketing Management & 1 \\
\hline 32 & 30 & Nigerian & International Business & 2 \\
\hline 33 & 24 & Syrian & Political Science & 2 \\
\hline 34 & 21 & Palestinian & Psychology & 2 \\
\hline 35 & 23 & Turkish & Economics & 1 \\
\hline 36 & 32 & Turkish & Online Services & 4 \\
\hline 37 & 22 & Ethiopian & Tourism & 2 \\
\hline 38 & 30 & Nigerian & Construction Engineering & 3 \\
\hline 39 & 27 & Lebanese & International & 2 \\
\hline 40 & 26 & Libyan & Banking and Accounting & 2 \\
\hline 41 & 46 & Turkish-Cypriot & International & 4 \\
\hline 42 & 30 & Turkish & Civil Engineering & 3 \\
\hline 43 & 23 & Syrian & Dentistry & 2 \\
\hline 44 & 20 & Namibian & Nursing & 2 \\
\hline 45 & 21 & Zambian & International & 1 \\
\hline 46 & 23 & Algerian & International & 3 \\
\hline 47 & 34 & Zimbabwean & International & 2 \\
\hline 48 & 51 & Turkish & International & 4 \\
\hline 49 & 42 & Turkish & International & 3 \\
\hline 50 & 32 & Qatar & International Business & 2 \\
\hline
\end{tabular}

The participants were grouped into three distinct ethnic groups that dominate in the organization which were Turkish, Africans and Arabs. Figure 1 shows the three ethnic groups that participated in this study. 


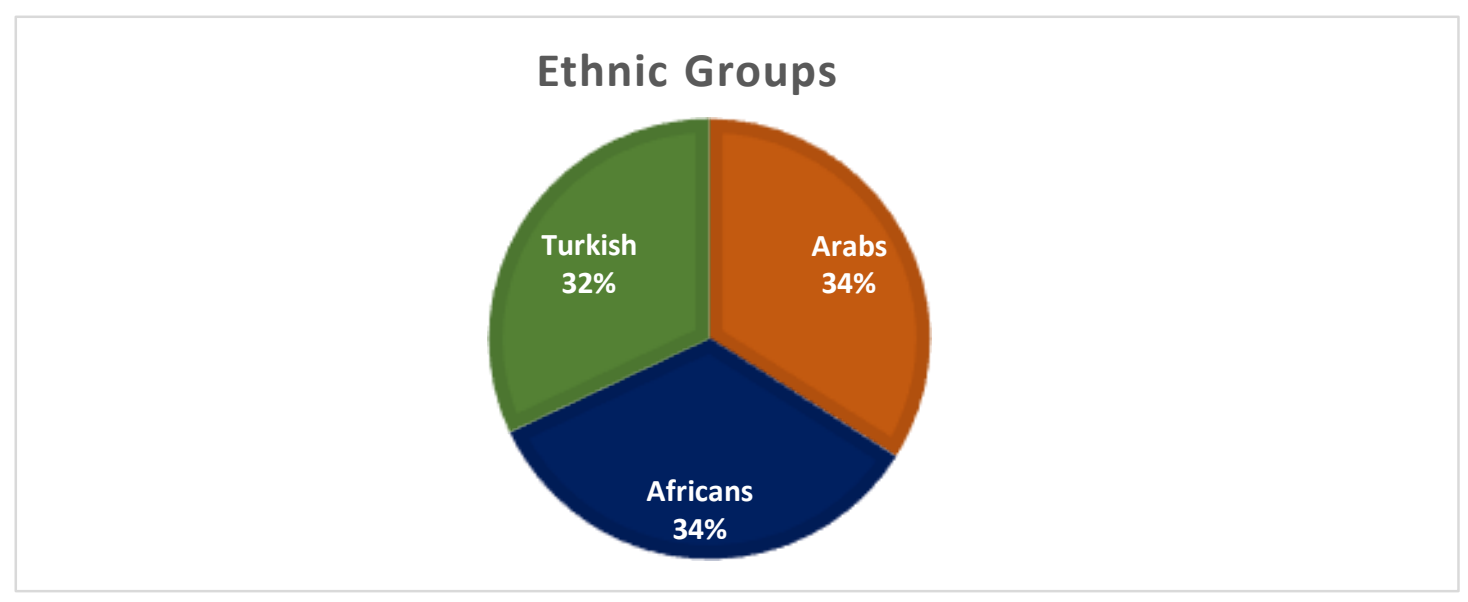

Figure 1. Ethnicity representation

The respondents were gender balanced in order to ensure that data was attained from both males and females. Gender representation of the three ethnicities is illustrated in Figure 2 below.

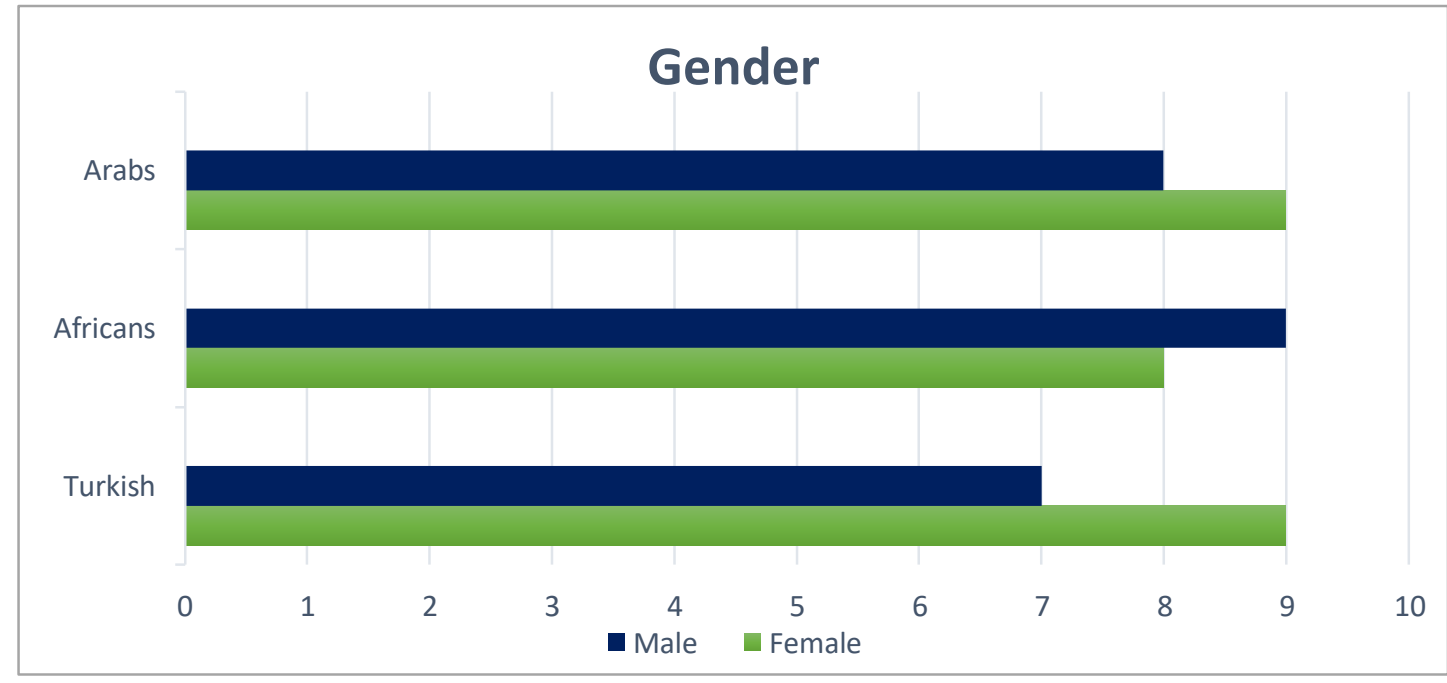

Figure 2. Gender representation of participants

\section{Findings}

For participants to feel comfortable with answering the questions, they were asked about their background which encompassed their gender, age and nationality. The responses that were given to the question "Have you encountered conflict before in the institution? Majority of respondents indeed had encountered conflicts in various places in the institution. Many mentioned that the conflict occurred in their department, cafeteria and during their registration process. It shows that the conflict did not occur in one place rather in different places located within the organization. Most respondents during the interview showed their concerns on misunderstanding arising mostly in the institution more than outside the institution.

The question that followed was "Do you think that conflict was influenced by the cultural differences that exist? Indeed, all three ethic participants highlighted that they agreed to the 
question and gave their explanation as to why they said so. African ethnicity was sixteen out of seventeen who agreed to this question. An example of the response (R.1) is presented below:

(...) Everyone comes from a different cultural background which encompasses their religious beliefs and way they communicate with others.....

Arabic ethnicity had eleven out of seventeen respondents that highlighted the fact that they were brought up in households that were strict and hence values are held highly from other ethnicities. Response that was given by (R.3) is stated below:

(...) Each individual is different in their own way because their approach to certain situations differs due to their cultural background hence they have a certain value system that is within them which is unchangeable. People uphold the values that are embedded in them hence a times people clash due to the unwillingness of respecting a person's moral values.

Twelve out of sixteen Turkish participants mostly pointed out that the different cultural backgrounds that people originate from impacted on conflicts that transpire amongst people or groups within the society. An example of response that was given by (R.4) is expressed as follows:

(...) It would take time for people to adjust to the fact that everyone has a different cultural background that is unique in their own way hence conflicts may be influenced when they stereotype others.

The information that was obtained from the interview pertaining to the question showed that the reasons that were given by participants were different in terms of cultural backgrounds, different values and the issue of people being stereotyped by others. Many respondents continuously gave the same reasons to the question they were asked.

Another question that was asked "What cultural differences do you feel influence conflict in the institution?" Majority of respondents explained the differences that were in line with cultural theories that were explained in the literature showing that the differences in culture are seen from cultural dimensions that exist around the world.

Under the African ethnicity, majority of respondents highlighted that the issue of difference in skin color influences conflict as well. Many respondents emphasized that discrimination that they encounter from other ethnicities influences majority of conflicts that arise. Communicating through gestures and facial expression is a difference in culture that people use when expressing their agreement or dislike to something mentioned which often is interpreted differently from one cultural context to another leading to conflicts. In addition, most of the female respondents felt the fact that they are being underestimated by males in the organization and hence they are not being given adequate opportunities.

The Arabic ethnicity respondents mentioned that in their culture they were not allowed to have contact with the opposite sex even if it is a greeting and hence the other cultural contexts may not understand this cultural difference which they misinterpret as being rude or mean 
causing conflict. The minority of respondents stated that they had faced discrimination because of their ethnicity mainly because they could not speak the language spoken in the country.

Respondents under the Turkish ethnicity mentioned that body language and gestures were different they faced as having an influencing element to conflicts. Respondents highlighted the fact that facial expression that people make when communicating with other people from a cultural context is different and may be misunderstood. It may be seen as provoking to the other person of disrespectful which often influences an altercation to arise.

When people have a better understanding that there are different ethnicities that exist in societies and the styles that are used in communication are different, it would eliminate negativity and assist in accepting that each individual is different in their own way. The cultural dimensions that support the cultural differences highlighted by the respondents are Hofstede's masculine-feminine dimension and Trompenaars neutral-emotion dimension. This shows that cultural differences highlighted influence on conflict within the organization greatly.

Another question that was asked "What cultural factors do you think influence conflicts within the institution?" Majority of respondents felt that cultural factors such as language, religion and values were influential in conflicts. A follow up question asked on "Why do you think the cultural factors you selected are the most influential in conflicts?"

Under the African ethnicity, majority highlighted that language and values were the factors they felt had an influencing effect on conflicts. Examples of responses given by (R.19) is expressed below:

(...) Religion determines the type of a person you will be and hence conflict may arise due to the fact that people are not willing to accept the different religious beliefs people have. Language barrier influences conflict in that people will not understand one another due to not being able to communicate the same language hence miscommunication between parties.

In addition, another participant (R.22) mentioned that:

(...) An individual's upbringing shapes the values that a person has when growing up hence when operating in an organization that has people who do not uphold the values that you have my cause clashes to arise.

The respondents who were under the Arabic ethnicity mentioned that religion, communication (language barrier) and values were factors they viewed to be influential in conflicts. Most of the participants emphasized the fact that language barriers within the institution makes communication difficult for both staff and students. Sample of the responses that (R.23) and (R.26) gave are expressed in the following statements:

(...) The beliefs that an individual has may be different to another tends to influence conflict due to people lacking understanding. When meeting other people who are from the same religion who do not adhere to the laws tends to instill a person some sort of urge to approach others to change their ways which influences conflict.... 
Most of the international students find it difficult to communicate with employees (cleaners, cafeteria staff, and academic staff) who do not understand or speak English well. This often influences conflict to arise between parties when people misinterpret and do not understand what the other person is trying to communicate with them.

(...) The language barrier makes it difficult for people to explain or air out their grievances they face to in the institution with others who do not understand English language that much...

Majority of the Turkish respondents emphasized that communication and values were the most influential factors. Some respondents elucidated that most international students and staff are not willing to learn the local language for easier communication because they may feel there is no need for them to learn it. It tends to influence conflict in that the people may view themselves better than others. Responses that were given by (R. 25) and (R. 27) are articulated below:

The inability for people to express themselves better when communicating has prompted people to misinterpret what an individual says and hence conclusively view others as being rude.

(...) The issue of people who understand English language tend to pretend that they do not hear what the other person is saying leads to misunderstanding to arise...

The issue of values has been seen to be very influential in that people are ignorant to other people's values.

(...) The respondent mentioned that different cultures interpret something that is done by another person or what they uphold may be of no importance to another culture and hence people block the idea that everyone is different in their own way.

The analysis showed that three cultural factors have a great influence on conflict within the institution. Many respondents from all the three ethnicities encountered conflict due to the various cultural factors. They gave their views and opinions which were mostly centered on cultural factors such as religion, values and communication (language) as the influencing factors of the conflicts. These factors were supported by various authors in their journals and book, influencing conflicts in various societies. Religion was a factor that was mentioned by many respondents in having an influencing part in conflict. This is supported by what Huntington (1993) mentioned that religion is a social factor that influences conflict. Weigel (1991) supported this notion that religion contributes to majority of conflicts in societies.

Gao (2002) stated that cultural-induced language conflict is influenced by improper communication between individuals. In addition, Shadid (2007) supported that conflict is influenced when there is miscommunication that arises with people from different cultural contexts. Garcia and Canado (2005) established that conflicts are also influenced when people come from diverse cultures and try to speak the same language which leads to miscommunication and lack of understanding due to the different ascents. 
People's values can be contradicting with others which leads to clashes occurring. Barash and Webel (2002) supported that when two parties have different ways of communicating their values to each other, their behavior towards one another tends to become negative.

Another question that was asked was "Do you think differences in personality influence conflict?" Fifteen out of seventeen African respondents felt that differences in personalities influence conflict greatly. Many of the respondents pointed out that this was due to the fact that people have differences in shared opinions, individualism and backgrounds. Response given by (R.37) is highlighted below:

\section{(...) People feel the need to fit in and hence not willing to adjust to the current environment or society they are operating in.}

Through the interviews, it was established that certain people in societies have the urge of feelings entitled which often poses as the greatest challenge they have with others. People are stubborn and they feel that things should go according to the way they want without considering others that lead to misunderstandings arising. Many of the respondents expressed that people are different and personalities cannot be changed since everyone's backgrounds impact greatly in molding an individual to become the person he/she is today.

Thirteen of the Arab respondents agreed that different personalities have a contributing factor in the rise of conflicts. Majority of the respondents highlighted that people share different opinions which are bound to contradict with others. Four of the respondents did not give explanation to why they thought personalities do not influence conflict rather they just disagreed with the question asked. An example of the response that was given by one participant (R.40) about their encounter is expressed below:

(...) Upon apologized to one student when pumping into her by mistake as she was rushing to class. Due to the differences in personalities, she did not take it lightly and blow things out of proportion as if she had intentionally done. The respondent did not understand why other person took it to heart considering she did not know her at all.

During the interviews, it was pointed out by some respondents that people need to understand different personalities exist and hence there is the need for people to learn to accept this and adjust to the differences.

Twelve out of sixteen respondents said "yes" while four respondents answered "no" under the Turkish participants. Analyzing the responses showed that individualism and different backgrounds were mentioned many times in the interviews. When people have huge personalities while others have a reserved type of personality, this may influence conflict. An example of what (R.41) highlighted is explained below:

(...) People have different personalities and hence conflict is inevitable between parties or groups involved in a discussion.... 
Analysis was made from the interviews that majority of respondents from all the three ethnicities felt that differences in personalities also influence conflicts in the institution. Responses were similar, as many of the participants highlighted some reasons that were alike emphasizing that people are different not only because of their cultural backgrounds but in the way they perceive things. This was supported in literature review by De Drue et al. (2007) that personality is seen as a contributing factor in most conflicts arising. Slocum \& Hellriege (2007) mentioned that when people have different personalities, it results in clashes arising because of the difference in views and opinions in a certain subject matter.

\section{Conclusion}

According to the literature and concocted interviews, it is seen that cultural differences influence conflict negatively mainly the people lacking proper knowledge of how other cultures operate. Cultural factors such as values, religion and communication (language) were noted as to having influenced conflicts greatly. This is because of people's resistance to learning, contradictions of people's values, lack of accommodation of other cultures and a tendency of people having a shift in attitude towards other ethnicities.

Conflict is influenced negatively when people overlook the cultural factors applied to all ethnicities operating within the organization. The fact that people are ignorant of the various cultural contexts that exist which often triggers conflicts with people from other cultures when there is lack of respect and proper understanding that communication styles are different. When an organization's structure lacks accommodation of different ethnicities, it influences people to have a negative attitude towards other cultures because the top management would not be leading by example. It affects the staff and students operating within the institution and hence people exhibit resistance and negativity towards certain people.

When an individual attacks another person on his way of doing thing thinking that he is doing wrong, it influences conflict by that an individual would be focusing on his own perception of the way things are done and do not give a room for the other person to do it on his own way. This applies to the diverse cultures that exist when African people come from different countries, they can do something using a different method, however, yielding the same results. The fact that people are quick to judge or rather feel their culture is better than others which often leads to having negative attitudes towards one another. Therefore, the literature used is in support of the results obtained from the interviews which showed that cultural differences influence conflict negatively within an organization mainly due to the issue of lack of knowledge.

\section{References}

Avruch, K. (2009). Cross-cultural conflict. Conflict Resolution, 1, 45-57.

Barash, D. P., \& Webel, C. P. (2002). Peace and conflict studies. California: Sage Publications.

Barki, H., \& Hartwick, J. (2004). Conceptualizing the construct of interpersonal conflict. International Journal of Conflict Management, 15, 216-245.

Bartos, O. J., \& Wehr, P. (2002). Using conflict theory. New York: Cambridge University Press.

Basset, P. (2005). Chiness and Australian stuents' cultural preceptions. A comparative study. Working Paper. Victoria University, Melbourne, Australia. Retreived from http://vuir.vu.edu.au/id/eprint/383.

Cole, M. (2005). Cross-cultural and historical perspectives on the developmental consequences of education. Human Development, 48, 195-216.

Coleman, P. T., \& Kugler, K. G. (2014). Tracking managerial conflict adaptivity: Introducing a dynamic measure of adaptive conflict management in organizations. Journal of Organizational Behavior, 35, 945-968. 
De Drue, C. K., Blom, J. C., \& Hagendoom, L. (2007). Conflict. Functions, Dynamics and Cross Level Influences, 69-79.

Dimas, I. (2007). Intragroup conflict and effectiveness: The moderate role of group inteligence. Journal of Conflict Management, $1-16$.

Denzin, N. K., \& Yvonna, S. L. (2000). Handbook of qualitative research. Thousand Oaks: Sage Publications.

Fisher, R. J. (2001). Cyprus: The failure of mediation and the escalation of a identity-based conflcit to an adversarial impasee. Journal of Peace Research, 38, 307-336.

Gao, H. (2002). Language contact - miunderstanding, confusion and conflicts. Intercultural Communication Studies, 3,107115.

Garcia, M. M., \& Canado, M. P. (2005). Language and power: Raising awareness of the role of language in multicultural teams. Language and Intercultural Communication, 86-104.

Gesteland, R. (2000). Cross-cultural business behavior: Marketing, negotiating, sourcing and managing across cultures. Copenhagen, Denmark: Copenhagen Business School Press.

Griffen, R. W., \& Pustay, M. W. (1999). International business: A managerial perspective (2nd ed.). Boston: Addison-Wesley Pubishing Company, Inc.

Gudykunst, W. B., \& Kim, Y. Y. (2003). Communicating with strangers: An approach to intercultural communication (2nd ed.). New York: McGraw-Hill.

Hadi, Z. A. (2004). Organizational culture and information management system in public organization. Journal of Public Sector Management, 2, 44-56.

Hall, S. (1990). The emergence of cultural studies and the crisis of the humanities. The MIT Press, 53, 11-23.

Halverson, B. C., \& Tirmizi, S. A. (2008). Effective multicultural teams: Theory and practice. New York: Springer.

Hatch, J. A. (2002). Doing qualitative research in education settings (2nd ed.). Albany: Suny Press.

Herriot, P. (2007). Religious fundamentalism and social identity. New York: Routledge.

Hofstede, G. (1980). Culture's consequences: International differences in work-related values. Beverly Hills, CA: Sage.

Hofstede, G., Hofstede, G. J., \& Minkov, M. (2010). Cultures and organizations: Software of the mind (Rev. 3). New York: McGraw-Hill.

Huntington, S. (1993). The clash of civilizations? New York: Foreign Affairs

Imada, T. (2012). Cultural narratives of individualism and collectivism: A content analysis of textbook stories in the United States and Japan. Journal of Cross-Cultural Psychology, 43, 576-591.

Kashima, Y. (2016). Culture and psychology in the 21st century: Conceptions of culture and person for psychology revisited. Journal of Cross-Cultural Psychology, 47, 4-20.

Kaushal, R., \& Kwantes, C. T. (2006). The role of culture and personality in choice of conflict management strategy. International Journal of Intercultural Relations, 30, 579-603.

Koerner, A. F. (2006). Models of relating - not relationship models: Cognitive representations of relating across interpersonal relationship domains. Journal of Social and Personal Relationships, 23, 629-653.

Ling, F. Y., \& Lim, S. S. (2007). Encounters between foreigners and Chinese: Perception and management of cultural differences. Engineering Construction and Architectural Management, 14, 501-518.

Luthans, F., \& Doh, J. (2012). International management: Culture, strategy, and behavior. New York: McGraw-Hill.

Mayring, P. (2014). Qualitative content analysis. Theoretical foundation, basic procedures and software solution. Klagenfurt: Pearson.

Mensa-Bonsu, B., \& Effah, P. (2003). Conflict management and resolution skills for managers of tertiary education institutions. Accra: National Council for Tertiary Education.

Mullins, L. J. (2007). Management and organizational behaviour (8th ed.). New Jersey: Prentice-Hall.

Oetzel, J. G., \& Ting-Toomey, S. (2003). Face concerns in interpersonal conflict: A cross-cultural empirical test of the face negotiation theory. Communication research, 30, 599-624.

Overton, A. R., \& Lowry, A. C. (2013). Conflict management: Difficult conversations with difficult people. Clinics in Colon and Rectal Surgery, 26, 259-264.

Raffery, J., \& Tapsell, J. (2001). Self-managed work teams and manufacturing strategies: Cultural influences in the search for team effectiveness and competitive advantage. Journal of Management, 11, 19-34.

Reilly, D., \& Neumann, D. L. (2013). Gender-role differences in spatial. A meta-analytic review. Sex Roles, 68, 521-535.

Robbins, S. P., \& Judge, T. A. (2011). Organizational behaviour (14 ${ }^{\text {th }}$ ed.) New Jersey: Prentice Hall.

Ross, k. (1997). But where's me in it? Disability, broadcasting and the audience. Media, Culture, and Society, 19, $669-677$.

Saroglou, V. (2008). Religion and psychology of values: Universal and changes. International Journal of Philosophy and Politics, 14, 247-272.

Saroglou, V., \& Cohen, A. B. (2013). Cultural and cross-cultural psychology of religion. In R. F. Paloutzian \& C. L. Park (Eds.), Handbook of the psychology of religion and spirituality (2nd ed.) (pp. 330-353). New York: Guilford Press.

Schat, A. H., Frone, M. R., \& Kelloway, E. (2006). Prevalence of workplace aggression in the U.S. workforce: Findings from a national study. In E. K. Kelloway, J. Barling, \& J. J. HurrellJr (Eds.), Handbook of workplace violence (pp. 47-89). Thousand Oaks, CA: Sage Publications

Schermerhorn, J. R., Hunt, J. G., Osborn, R. N., \& Osborn, R. (2004). Core concepts of organizational behaviour. New Jersey: John Wiley \& Son.

Schwartz, S. H. (1992). Universals in the content and structure of values: Theory and empirical tests in 20 countries. New York: Academic Press.

Shadid, W. A. (2007). Foundations of intercultural communication: Field of study and field of work. Leiden: Kluwer.

Slocum, J. W., \& Hellriegel, D. (2007). Fundamentals of organizational behaviour. USA: Thomas South Western.

Thomas, D. C. (2008). Cross-culture management essential concepts. Chicago: Sage. 
Thompson, L., \& Janice, N. (2000). Judgmental biases in conflict resolution and how to overcome them. In M. Deutsch \& P. Coleman (Eds.), The handbook of conflict resolution: Theory and practice (pp. 213-235). San Francisco, CA: Jossey-Bass. Ting-Toomey, S., \& Oetzel, J. G. (2001). Managing intercultural conflict effectively. Thousand Oaks, CA: Sage.

Triandis, H. C. (2001). Individualism-Collectivism and Personality. Journal of Personality, 69, 907-942.

Trompenaars, F., \& Hampden-Turner, C. (2004). Managing people across cultures. New York: Capstone Publishing Ltd.

Trompenaars, F., \& Hampeden-Turner, C. (1997). Riding the waves of culture: Understing cultural diversity in business (2nd ed.) London: Nicholas Brealey.

Trompenaars, F., \& Woolliams, P. (2003). Business cross cultures. New Jersey: Capstone Publishing Ltd.

Tung, L. L. (2002). Cultural differences explaining the differences in results in GSS: implications for the next decade. Journal for Management, 33, 177-199.

Weigel, G. (1992). Religion and Peace: An Argument Complexified. The Washington Quarterly, 14, $27-42$.

Weldon, E., \& Jehn, K. A. (1995). Examining cross-cultural differences in conflict management behavior: A strategy for future research. International Journal of Conflict Management, 6, 387-403.

Wood, W., \& Eagly, A. H. (2009). Gender identity. In M. Leary \& R. Hoyle (Eds.), Handbook of individual differences in social behavior (pp. 109-125). New York: Guilford.

Wood, W., \& Eagly, A. H. (2015). Two traditions of research gender indetity. Sex Roles, 73, 461-473.

Worchel, S. (2005). Culture's role in conflict and conflict management: Some suggestions, many questions. International Journal of Intercultural Relations, 29, 739-757.

Wurtz, E. (2005). Intercultural communication on web sites: A cross-cultural analysis of web sites from high-context cultures and low-context cultures. Journal of Compuer-Mediation Communication, 11, 274-299. 